\title{
Tree potential growth varies more than competition among spontaneously established forest stands of pedunculate oak (Quercus robur)
}

\author{
Dominique Lamonica $^{1} \cdot$ Joern Pagel ${ }^{1} \cdot$ Elena Valdés-Correcher ${ }^{2} \cdot$ Didier Bert $^{2} \cdot$ Arndt Hampe $^{2} \cdot$ Frank M. Schurr $^{1}$
}

Received: 1 April 2020 / Accepted: 1 July 2020 / Published online: 17 August 2020

(C) The Author(s) 2020

\begin{abstract}
Key message Analyses of dendrochronological data from 15 recently established tablished stands of pedunculate oak ( Quercus robur L.) revealed that functions describing potential tree growth in the absence of neighbours varied more between stands than functions describing competitive effects of conspecific neighbours. This suggests that competition functions can more easily be transferred among stands than potential growth functions.

Context The variability inherent in the natural establishment of tree stands raises the question whether one can find general models for potential growth and competition that hold across stands.

Aims We investigated variation in potential growth and competition among recently established stands of $Q$. robur and tested whether this variation depends on stand structure. We also tested whether competition is symmetric or asymmetric and whether it is density-dependent or size-dependent. Lastly, we examined whether between-year growth variation is synchronous among stands.

Methods Potential growth, competition and between-year growth variation were quantified with statistical neighbourhood models. Model parameters were estimated separately for each stand using exhaustive mapping and dendrochronology data.

Results Competition was best described with an asymmetric size-dependent model. Functions describing potential growth varied more among forest stands than competition functions. Parameters determining these functions could not be explained by stand structure. Moreover, annual growth rates showed only moderate synchrony across stands.

Conclusion The substantial between-stand variability in potential growth needs to be considered when assessing the functioning, ecosystem services and management of recently established $Q$. robur stands. In contrast, the relative constancy of competition functions should facilitate their extrapolation across stands.
\end{abstract}

Keywords Interpopulation variability · Distance and size dependence $\cdot$ Neighbourhood effect $\cdot$ Interannual variability · Bayesian modelling

\section{Introduction}

In contrast to many regions of the world, Europe has experienced an increase in forest cover over the last decades

Handling editor: Irene Martín-Forés (Guest Editor)

This article is part of the topical collection on Establishment of second-growth forests in human landscapes: ecological mechanisms and genetic consequences

Dominique Lamonica

dominique.lamonica@gmail.com

Extended author information available on the last page of the article.
(Díaz et al. 2019). Due to agricultural land abandonment (Fuchs et al. 2013; Potapov et al. 2015; Song et al. 2018) and the reduction in farmlands in many European regions, forest area has increased by 0.8 million hectares each year since 1990 (Unece 2015). This trend should continue in coming years (Schroter et al. 2005). Newly establishing forest areas may have effects on community composition, net primary production, rates of decomposition and nutrient cycles (Whitham et al. 2006; Allan et al. 2012). They may deliver ecosystem services, such as carbon storage, increasing potential habitat for associated species, biodiversity "refuges" or corridors for species migration, but they may also cause threats such as fire risk increase, invasive species spread or loss of open landscapes, in cases 
of uncontrolled spread (Rey Benayas and Bullock 2012). To be able to adequately manage the passive restoration of agricultural lands, it is necessary to deepen our understanding of the underlying mechanisms of forest establishment. Several recent studies have been conducted on various processes occurring in establishing forests. These include growth patterns and sensitivity to climate (Alfaro-Sảnchez et al. 2019), effect of shrub cover or herbivory on recruitment (Ramirez and Diaz 2008; Cruz-Alonso et al. 2019; Rey Benayas et al. 2015) or carbon storage (Vilà-Cabrera et al. 2017). Nevertheless, the dynamics of natural forest regeneration and the underlying demographic processes, such as growth and competition, still remain to be further explored.

In general, the dynamics of tree populations are difficult to describe and model because the fundamental demographic processes driving forest dynamics, such as individual growth, fecundity, dispersal, recruitment and mortality, strongly depend on the spatial arrangement and size structure of neighbouring trees. If forest establishment occurs naturally (rather than as a consequence of reforestation), established tree populations can show particularly strong variation in spatial and size structure. Moreover, founder effects can cause substantial variation in the genetic structure of these populations that can have profound consequences for ecological functioning (Whitham et al. 2006). This raises the question of whether one can find general models for tree growth and competition that hold across multiple recently established tree populations. To do this, one must also consider that an individual's growth varies from year to year, according to temporal variation of environmental conditions, in particular temperatures and water availability during early summer in temperate forests (Rozas 2005; Scharnweber et al. 2011; Canham et al. 2018).

Competition between individuals is a main driver of tree population dynamics (Pacala et al. 1996; Bugmann 2001). Spatially restricted competition for light, nutrients and/or water gives rise to negative effects of neighbours on the growth of a target individual. These competitive effects are generally expected to increase with the size of neighbours. They can be described with size-dependent neighbourhood models. Alternatively, competition can be described by a density-dependent neighbourhood model in which the competitive effect of neighbours is independent of their size. Additionally, competition can be either symmetric (if a target tree experiences competition from all neighbours) or asymmetric (if a target tree only experiences competition from larger neighbours). Asymmetric competition arises when resources are not homogeneously distributed in space or when resource supply is directional (Schwinning and Weiner 1998). Competition for light is often assumed to be more asymmetric than competition for soil resources (Schenk 2006) and can be considered as the major competition process in tree populations (Bourdier et al. 2016).

Various neighbourhood models where individual growth is modelled as a function of size and distance to neighbours have been developed and used (Bella 1971; Hegyi 1974; Lorimer 1983; Wimberly and Bare 1996; Berger and Hildenbrandt 2000; Canham et al. 2004; Canham et al. 2006; Uriarte et al. 2004a; Uriarte et al. 2004b; Stadt et al. 2007; Coates et al. 2009; GómezAparicio et al. 2011; Das 2012; Buechling et al. 2017; Latreille et al. 2017). Many of the aforementioned studies investigated tree growth and neighbourhood competition for populations of mixed species and/or single-species populations, but not how tree growth and competition vary between populations of the same species, except Latreille et al. 2017 who focussed on climate effects on silver fir growth. In other studies (Canham et al. 2006; Stadt et al. 2007; Buechling et al. 2017), different locations were compared but they comprised different mixtures of species and concerned established populations. Several studies have underlined how growth and/or competition can vary between stands of different ages (Alfaro-Sänchez et al. 2019), or over spatial extents ranging from a few hundred meters to a couple of kilometres (Linares et al. 2010; Fraver et al. 2014), or across Europe (Ruiz-Benito et al. 2014). However, they generally describe competition through global competition indices, whereas neighbourhood models have the advantage that they include a free parameter that describes the spatial scale of competitive interactions.

This study presents neighbourhood model analyses of 15 recently established stands of pedunculate oak (Quercus robur L.) in south-western France. For each stand, we use comprehensive data on the spatial location and annual growth increments of individuals to quantify potential tree growth in the absence of neighbours as well as intraspecific competition with neighbours, while accounting for between-year variation in growth. These analyses serve to address four objectives: (1) to determine whether competition is symmetric or asymmetric and whether it is size- or density-dependent; (2) to quantify the extent to which potential growth and competition functions vary among stands; (3) to test whether this between-stand variation can be explained by the age, size or spatial structure of stands; and (4) to test whether between-year variation in tree growth is synchronous across stands. 


\section{Materials and methods}

\subsection{Data collection}

\subsubsection{Study area}

The study area was located between 15 and $45 \mathrm{~km}$ southwest of Bordeaux, France $\left(44^{\circ} 41^{\prime} \mathrm{N}, 00^{\circ} 51^{\prime} \mathrm{W}\right.$ ) (Appendix Fig. 6). This region is covered by 1 million ha of Pinus pinaster L. Widespread deciduous tree species include holm oak (Q. ilex L.), Pyrenean oak (Q. pyrenaica Willd.), silver birch (Betula pendula L.) and different willows (Salix spp.). The region's climate is oceanic (mean annual temperature of $12.8^{\circ} \mathrm{C}$ and annual precipitation of $873 \mathrm{~mm}$ over the last 20 years), and the soil is sandy (spodosols), very dry during summer and wet during winter (see Valdès-Correcher et al. (2019) for more details on soil and climate characteristics).

\subsubsection{Sampling and dendrochronology analysis}

We randomly selected 15 forest stands from the 18 isolated newly established oak forest stands selected by ValdésCorrecher and colleagues (see Section 6 Appendix Table 3 for further information on forest stand characteristics). In the study forest stands, each $Q$. robur individual above $3 \mathrm{~cm}$ of diameter at breast height ( $\mathrm{dbh}$ ) was mapped (using GPS) and its dbh was measured in summer 2018 (Bert and Hampe 2020). All 661 living individuals (above $3 \mathrm{~cm}$ $\mathrm{dbh}$ ) were cored once (in summer 2018) with a 5-mm Pressler increment borer. For the majority of these (98\%), the drilling height was $30 \mathrm{~cm}$. After sampling, cores were air dried. The tree ring measurement was done optically, after scanning cores at $1200 \mathrm{dpi}$. The chronologies were visually cross-dated at the time of the measurement with Windendro 2017a, using the Gleichläufigkeit index (Schweingruber 1988) and some pointer years with usually low or high level of growth (see Alfaro-Sánchez et al. 2020 for a detailed description of the field sampling, laboratory procedures and data collection).

In the case of multistemmed trees, we calculated the basal area for each stem based on the measured dbh and summed those basal areas to obtain the total basal area of the tree. Then, the ratio between the basal area of the cored stem and the total basal area of the tree was used as a correction factor to estimate the annual growth increment of the entire tree from the growth increment of the cored stem.

Tree age at the end of 2017 was calculated as the sum of the number of measured rings, the number of missing rings at the pith, the number of missing rings at drilling height and the number of missing rings under the bark. When the core passed the tree pith, the number of missing rings at the pith was set to 0 . Otherwise, it was estimated based on the estimated distance to the pith and the growth of the five closest rings to the pith. The number of missing rings at drilling height was set to 3 when the drilling height was $30 \mathrm{~cm}$ (for $98 \%$ of the individuals). For the remaining $2 \%$ of individuals, which were drilled higher, we added more years assuming an average height growth of $10 \mathrm{~cm}$ per year (Gerzabek et al. 2017).

\subsection{Modelling}

\subsubsection{Model description}

The theoretical approach developed by Canham and colleagues states that the absolute growth rate, i.e. the observed diameter growth rate (width per year), is the product between the hypothetical diameter growth rate of a "free-growing-tree" and the potential factors that may reduce this growth, such as neighbour effects (crowding and shading (Canham et al. 2004; Uriarte et al. 2004a, b; Stadt et al. 2007; Das 2012)), and environmental factors: site effect, climate, pests (Canham et al. 2006; Coates et al. 2009; Gómez-Aparicio et al. 2011). There is no consensus on how to link diameter growth and size (Coates et al. 2009). Nevertheless, the aforementioned studies have modelled tree growth according to size using a lognormal function because of its flexibility and empirical support.

For each individual $i$ and year $t$, we described the observed ring width $Y_{i, t}$ as a function of the focal individual's size $X_{i, t-1}$, namely dbh, at time $t-1$, and the neighbourhood effect $N E_{i, t}$ at time $t-1$.

For individual $i$, we modelled the effect of $\mathrm{dbh} X_{i, t-1}$ at year $t-1$ on the potential growth rate (i.e. the growth rate without competitors) at year $t$ (in $\mathrm{mm} /$ year) $g_{i, t}$ as:

$g_{i, t}=g_{m} \times S\left(X_{i, t-1}\right)$

with $g_{m}$ the maximum growth rate (mm/year) and $S\left(X_{i, t-1}\right)$ the lognormal growth-size relationship:

$S\left(X_{i, t-1}\right)=\exp \left(-0.5\left(\frac{\log \frac{X_{i, t-1}}{x_{0}}}{x_{b}}\right)^{2}\right)$

where $x_{0}$ is the dbh at maximum growth rate $(\mathrm{cm})$ and $x_{b}$ the shape parameter (larger values lead to a more shallow relationship between $\mathrm{dbh}$ and growth rate).

The neighbourhood effect $N E_{i, t}$ on the target individual $i$ at year $t$ is modelled as an inverse function of the distance $D_{i, j}$ (m) between the individual and its neighbours $j$ (within a radius of $50 \mathrm{~m})$ and an effect of the neighbour dbh $f\left(X_{j, t}\right)$ : 
$N E_{i, t}=\sum_{j=1}^{n} \frac{f\left(X_{j, t}\right)}{D_{i, j}^{\beta}}$

where $\beta$ describes how sharply the neighbour effect decreases with distance. We also tested a Gaussian kernel to describe the decline of competitive effect with distance, as used in Nottebrock et al. (2017), but this model failed to converge.

We tested four different models describing the alternative competition hypotheses and one model without competition. In the size-dependent models, the competitive effect of neighbours depends on their size whereas in the densitydependent models all neighbours have in principle the same competitive effect. In the asymmetric models, trees only respond to the competitive effects of larger neighbours whereas in the symmetric models they respond to competition by all neighbours. For the no competition (NC) model, we set $N E_{i, t}=0$. For symmetric density-dependent competition (SDC), neighbour effects are independent of neighbour size so that $f\left(X_{j, t}\right)=1$ for all neighbours $j$. For symmetric size-dependent competition (SSC), neighbour effects increase with neighbour size and $f\left(X_{j, t}\right)=$ $\log \left(X_{j, t}\right)$ for all neighbours $j$. For asymmetric densitydependent competition (ADC), only neighbours that are larger than the focal plant have a (size-independent) neighbour effect so that $f\left(X_{j, t}\right)=1$ for neighbours $j$ which verify $X_{j, t}>X_{i, t}$ and 0 otherwise. Finally, for asymmetric size-dependent competition (ASC), $f\left(X_{j, t}\right)=\log \left(X_{j, t}\right)$ for neighbours $j$ which verify $X_{j, t}>X_{i, t}$ and 0 otherwise. We used the logarithm of dbh rather than the dbh because it was a better explanatory variable for our dataset.

The competition effect $C_{i, t}$, which is the reduction in the potential growth rate of individual $i$ at year $t$ is then:

$C_{i, t}=\exp \left(-a \times N E_{i, t-1}\right)$

with $a$ the sensitivity to competition.

We included an annual random effect $\epsilon_{t} \sim \mathcal{N}\left(0, \phi^{2}\right)$ on the logarithm of growth rate at year $t$. The logarithm of the realised growth rate of individual $i$ at year $t, y_{i, t}$, including the competition effect and the annual random effect, is thus:

$\log \left(y_{i, t}\right)=\log \left(g_{i, t} \times C_{i, t}\right)+\epsilon_{t}$

The logarithm of the observed ring width $Y_{i, t}$ for individual $i$ at year $t$ follows a normal distribution:

$\log \left(Y_{i, t}\right) \sim \mathcal{N}\left(\log \left(y_{i, t}\right), \sigma^{2}\right)$

\subsubsection{Statistical analysis}

Parameter estimation For each of the five model types (NC, SDC, SSC, ADC and ASC), parameters were estimated independently for each of the 15 forest stands. The models were fitted in a Bayesian framework using Markov Chain Monte Carlo (MCMC). We defined vague prior distributions for each parameter (Table 1) and we used the same prior distributions for each inference process. MCMC computations were performed using the rjags $\mathrm{R}$ package (Plummer 2009; $\mathrm{R}$ Core Team 2018) (JAGS version 4.3.0, $\mathrm{R}$ version 3.4.4, rjags version 4-6). For each model and forest stand, 30,000 iterations were performed for each of three chains and the 25,000 first iterations were discarded as burn-in, leading to 15,000 values for the posterior distributions. To check convergence, we used the Gelman and Rubin (1992) convergence diagnostic. All models converged (see Appendix Table 4 for convergence diagnostics of the ASC model). For plotting and prediction of model functions, the obtained posterior distributions were subsampled to 1000 parameter combinations. For each forest stand, we computed Bayesian $R^{2}$ according to Gelman et al. (2018).

Model comparison In order to find the most appropriate competition model for each forest stand, we computed the Deviance Information Criterion (DIC) (Spiegelhalter et al. 2002) for the five different models fitted to the same data, and identified for each forest stand the DIC-minimal model.

Among-forest stand variation of potential growth and competition To quantify the variation of potential growth and competition among forest stands, we computed the respective functions for each forest stand using posterior medians of parameters. Specifically, we calculated potential growth rate $g(X)(1)$, growth-size relationship $S(X)$ (2) and the competitive effect on growth $C(X)((4)$, for a focal tree that has a single larger neighbour of $10 \mathrm{~cm} \mathrm{dbh}$ ). For each of the 15 forest stands, potential growth rate and the growth-size relationship were predicted for $12 \mathrm{dbh}$ values that were equally spaced between 5 and $60 \mathrm{~cm}$. This covers the dbh range in which most individuals lie. For each of the $12 \mathrm{dbh}$ values, we computed the coefficient of variation of the 15 predicted potential growth rates and growth-size relationships (one prediction per forest stand). We thus obtained 12 coefficients of variation (one per dbh value) that quantify to what extent the potential growth rate and the growth-size relationship vary among forest stands. Similarly, for each forest stand, the competitive effect of a neighbour was predicted for 12 distance values that were equally spaced from 1 to $12 \mathrm{~m}$ (above $12 \mathrm{~m}$ the competitive effect is very close to 1 for all stands). We thus obtained 12 coefficients of variation representing the among-stand variability of competition functions.

Effects of stand structure on growth and competition functions In order to investigate the effect of stand structure 
in space, size and age on growth and competition functions, we calculated seven variables. For spatial structure, we selected the number of trees, the density and the average nearest neighbour distance (i.e., for each forest stand, we recorded the distance to the nearest neighbour of each individual and computed the mean of those distances). For size structure, we selected the mean and standard deviation of the size (dbh) distribution. For age structure, we selected the maximum and the mean age. For each combination of a model parameter and a forest stand structure variable, we used the parameter posterior distributions (15,000 values) for the different forest stands and performed 15,000 linear regressions of the sampled parameter values against the forest stand structure variable, using the lme $4 \mathrm{R}$ package (version 1.1-17) (Bates et al. 2015).

\section{Results}

\subsection{Model comparison}

Competition among Quercus robur trees was found to be asymmetric rather than symmetric: the asymmetric models (ADC and ASC) had a lower DIC than the symmetric models (SDC and SSC) for all forest stands except three (Table 2). Between the two models describing asymmetric competition, the size-dependent version had a lower DIC than the density-dependent version for all but one of the 15 stands (Table 2), even though competition asymmetry was more important than size dependence (DIC of ADC model was overall lower than DIC of SSC model). Across forest stands, the "predominantly best" model was thus the asymmetric size-dependent competition model. For better comparability, all following results on inter-forest stand variation are therefore only shown for ASC model.

\subsection{Model fit and parameter estimation}

The data were overall satisfactorily described by the model: between 94.0 and $96.9 \%$ of the observed data are within the $95 \%$ credibility interval of the predicted data. The fit of median predictions to the observed data (Fig. 1) varied between forest stands, being satisfactory for some stands (A, $\mathrm{F}, \mathrm{K}, \mathrm{L}$ ) to poor for some others $(\mathrm{B}, \mathrm{O}, \mathrm{P})$. The proportion of variance explained by the model ranged from 0.21 to 0.73 (mean of $R^{2}$ distribution, Fig. 1).

We obtained overall narrow posterior distributions for almost all parameters compared with the prior distributions, suggesting that sufficient information was available from our data to accurately estimate model parameters (Fig. 2). The narrow posterior distributions of parameters led to small uncertainty around the potential growth rate and competition functions (Appendix Fig. 7).

\subsection{Variability across forest stands and effect of forest stand structure}

Parameter estimates varied among forest stands (Fig. 2) which led to different potential growth rate and competition effect functions for each forest stand (Fig. 3, predictions with the median values of parameter posterior distributions). However, potential growth functions were overall more variable across forest stands than competition effect functions (Fig. 3). Different shapes of the potential growth function arise from variation in the value of the $d b h$ at maximum growth rate $x_{0}$ (Fig. 2) (potential growth rate can be monotonically increasing with size for high $x_{0}$ or show an intermediate size optimum for lower $x_{0}$ ). The between-stand coefficients of variation of the potential growth rate $g(X)$ and the growth-size relationship $S(X)$ were higher than the coefficients of variation for competitive effect $E(X)$ (Fig. 4). Hence, competition functions varied less between stands than potential growth functions. The bootstrap linear regression of parameter values against forest stand structure variables showed no significant effect of the forest stand structure on parameter estimates (see Appendix Fig. 8).

\subsection{Annual variation in growth}

There is no obvious consistency in the annual effects on growth across forest stands: for a given year, the median values of $\epsilon_{t}$ are overall variable among stands (Fig. 5). Some forest stands showed a lot of inter-annual variability in growth rates, while some others showed very little variation across years (Appendix Fig. 9). Nevertheless, some years could be identified as overall "positive years for growth", when the median value of $\epsilon_{t}$ is positive for more than $75 \%$ of the forest stands. Those years are the following: 1993, 1994, 2000, 2003, 2004 and 2007. Similarly, some years could be identified as overall "negative years for growth". Those years are the following: 2001, 2015, 2016 and 2017.

\section{Discussion}

Mode of competition The model describing size-dependent asymmetric competition generally described the growth data best (Table 2). This implies that smaller trees are more sensitive to competition, as stated in previous studies (Hegyi 1974; Schenk 2006; Bourdier et al. 2016). It might indicate that shading is the dominant source of competitive pressure (Canham et al. 2004). Although in 

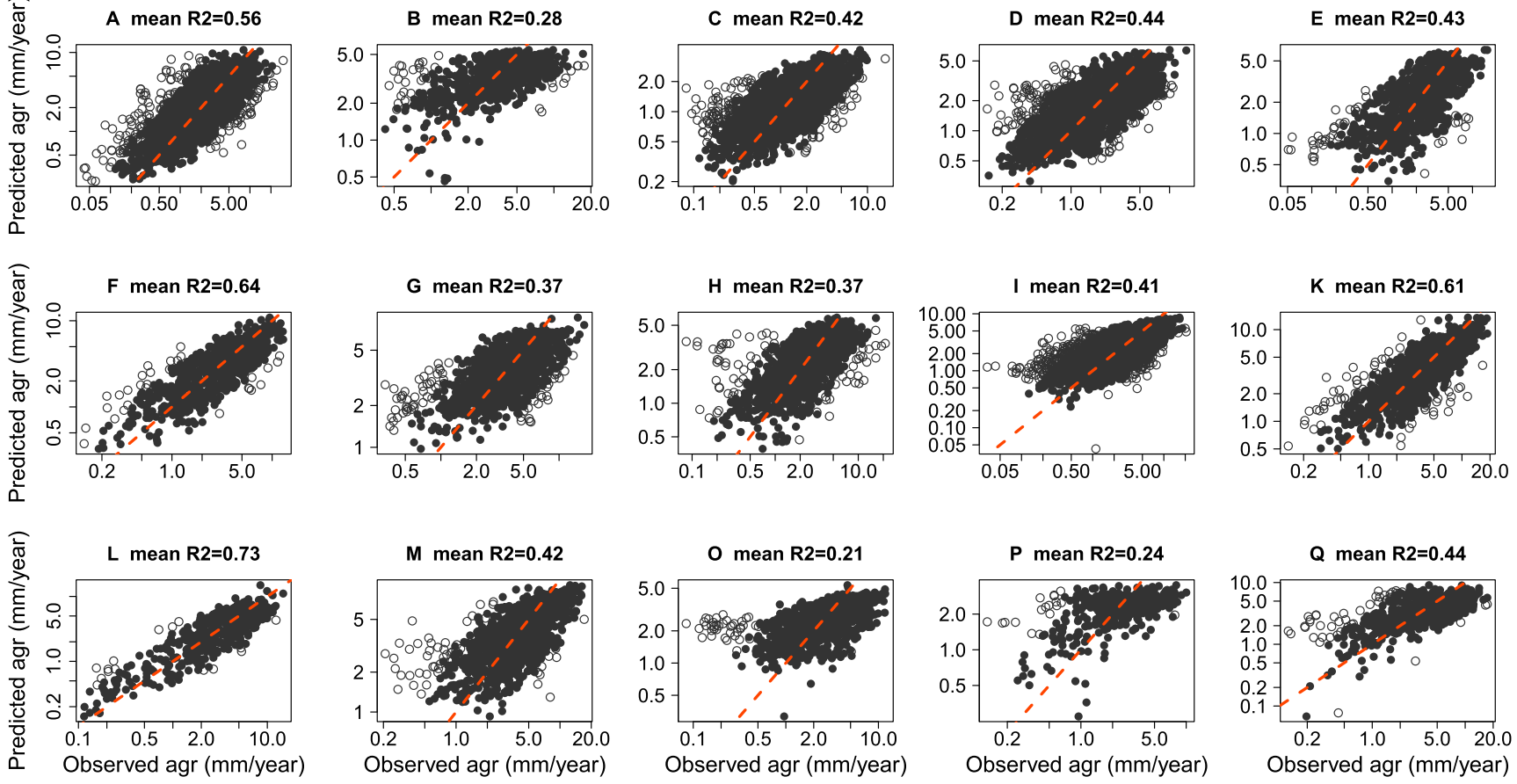

Fig. 1 Observed and predicted median absolute growth rates for each forest stand, with the asymmetric size-dependent competition model. Dots are full when the corresponding observed data point was within

the $95 \%$ credibility interval of predicted data and they are empty when the corresponding observed data point was outside the $95 \%$ credibility interval of predicted data. Dashed red line is the identity line

heterogeneous soils size-asymmetric root competition may also occur, root competition is rarely as asymmetric as shoot competition (Schenk 2006; Rasmussen et al. 2019). Moreover, in dry conditions, size-asymmetric competition may become increasingly symmetric at later stages of stand development, possibly as a result of decreasing soil water availability (Masaki et al. 2006). Competition for light will be particularly important in later stages of forest stand establishment, when the canopy increasingly closes as the first founder trees grow large and exert strong competition on later and smaller recruits.

Potential growth and competition functions Overall, the value ranges of estimated growth parameters seem in accordance with previous studies using this growth model (Canham et al. 2004; Uriarte et al. 2004a, b; Stadt et al. 2007; Das 2012). In several studies, the neighbour size is scaled in the competition equation, with values ranging from 0.7 to 3.5 depending on the species (Canham et al. 2004; Uriarte et al. 2004a, b; Stadt et al. 2007; Das 2012), while we used logarithm of dbh, suggesting an overall weaker effect of neighbour size in our forest stands. Concerning competition kernel shape, $\beta$ has often been estimated below 1 (Canham et al. 2006; Stadt et al. 2007; Coates et al. 2009; Das 2012), while it was above 1 for a majority of our forest stands, leading to a quite steeper decline of competitive effects with distance. Growth variability at population level has previously been observed between two sets of five silver fir stands along an elevation gradient (Latreille et al. 2017). Our finding that competition functions are more consistent across populations than functions describing potential growth is in accordance with results of the global (and much coarser scale) study of Kunstler et al. (2016).

Goodness of fit and uncertainty sources Although the residual variance in predicted growth rates remains large for some forest stands (Fig. 1), we obtained satisfactory fits of the model to the data, when comparing $R^{2}$ obtained in similar studies, which generally ranged from 0.10 to 0.60 (Canham et al. 2004; Uriarte et al. 2004a, b; Stadt et al. 2007; Das 2012), but reached 0.40 to 0.90 in Coates et al. (2009). Uncertainty around the potential growth and competition functions (deriving from parameter estimation uncertainty) was low and in general inter-annual effects did not explain interindividual variation. The exhaustive sample of the forest stands is likely to lead to this rather low uncertainty. A major part of the individual variability in observed growth is not explained by the competition process itself, nor the annual variation in growth, nor by uncertainty in parameter estimation, but is probably mainly due to intrinsic biological variation between individuals, or by individual-year interactions (Clark 2010). In addition, damage to the global health of the individual, such as physical damage, herbivory, pathogens or pests, can affect growth (Hansen and Goheen 2000; Dobbertin et al. 2001; Wood et al. 2003). 
(a) Maximum growth rate

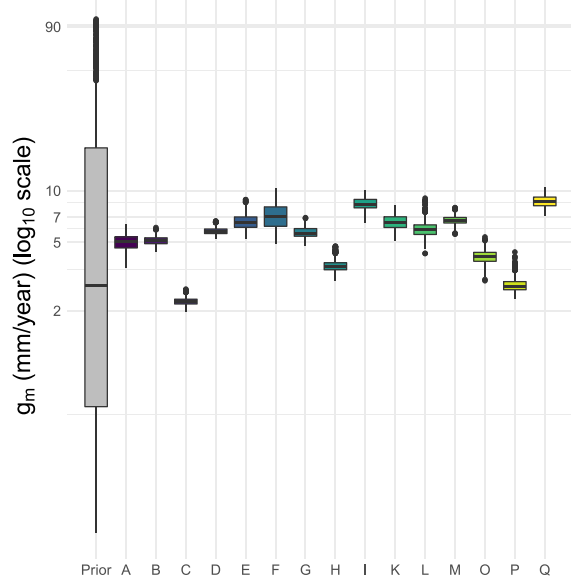

(d) Sensitivity to competition

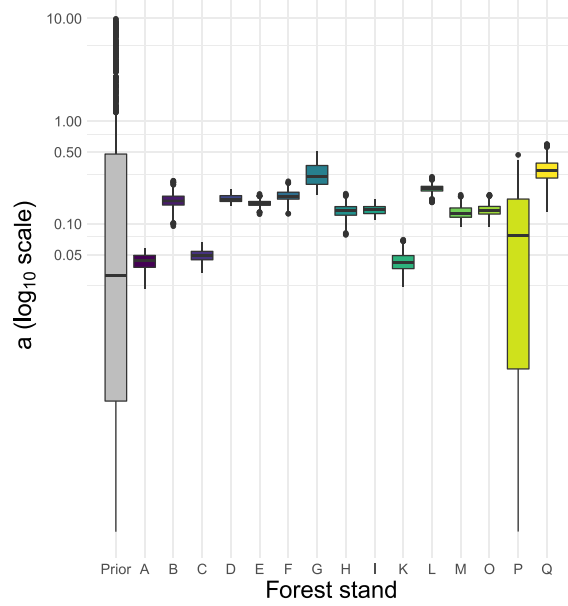

(b) Dbh at maximum growth rate

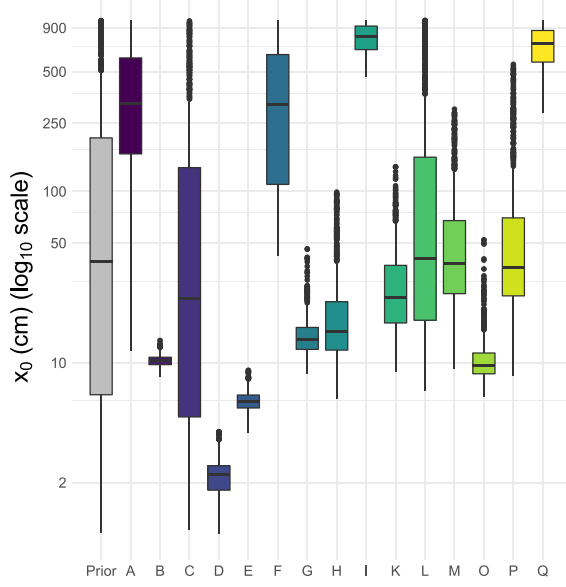

(e) Scale of neighbour effect with distance

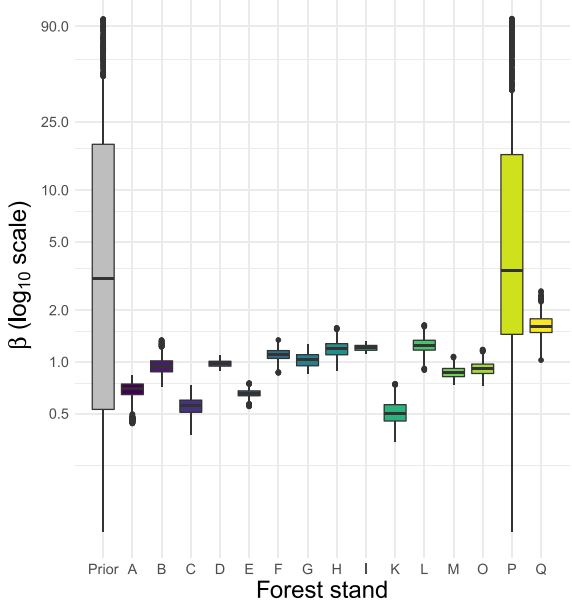

(c) Shape of the growth curve

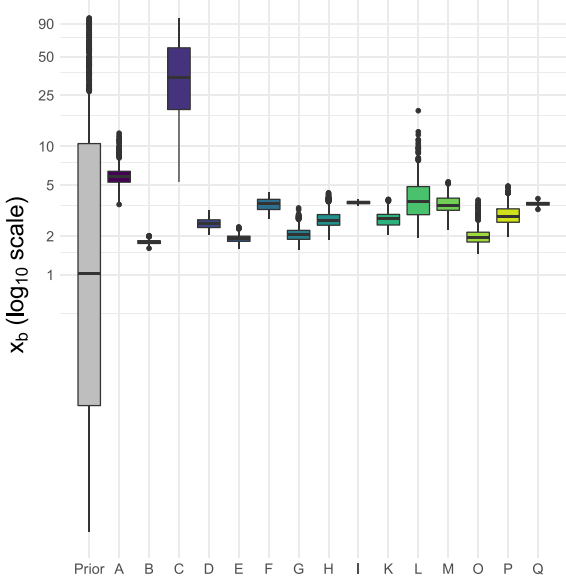

(f) Standard deviation of log(growth rate)

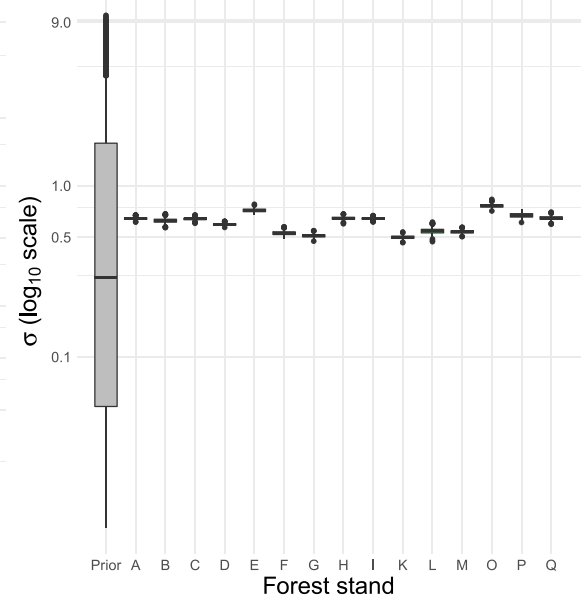

Fig. 2 Posterior distribution (1000 parameter combination sample) of the parameters for each forest stand, estimated by the asymmetric size-dependent competition model

Among-stand variability in potential growth functions The potential sources of variation in potential growth functions are numerous. Forest stand history may have influenced growth patterns, through past management of the surroundings and the forest stand itself and non-human disturbances such as storms or fire (Rademacher et al. 2004; Davis et al. 2005; Rigg 2005). Mortality and thinning events might have occurred in the past, but would not be directly observed in the available data. Such events have been shown to affect growth, and their effects can also be delayed in time (if a large neighbour of a target tree dies, the target tree would not immediately develop roots and crown structures to exploit the newly available resources) (Wright et al. 2000). Additionally, variation in potential growth functions could be due to herbivory which varies substantially between the studied oak stands (Valdès-Correcher et al. 2019). Moreover, local environmental conditions have probably had a large impact on growth as micro-topographic conditions differ among forest stands. Since developing forests have been found to be particularly sensitive to low water availability and high temperature (Coll et al. 2013; Madrigal-Gonzälez and Zavala 2014; Ruiz-Benito et al. 2014), differences in the frequency and intensity of drought across stands could lead to subsequent variability in growth across forest stands.

The observed differences in potential growth functions were due to both variation in maximum growth rate $g_{m}$ and in growth-size relationship $S(X)$ and may result from genetic and environmental influences (as assumed by Canham et al. 2004): genetic variability might play a part in determining potential growth and especially sensitivity to environmental factors influencing growth (genotype xenvironment interaction) (Atwood et al. 2002). For example, trees are likely to respond to temperature on a genetic basis at a provenance level (Saxe et al. 2001). A recent study on the tree individuals investigated here revealed considerable genetic effects on leaf herbivory 
(a) Potential growth rate

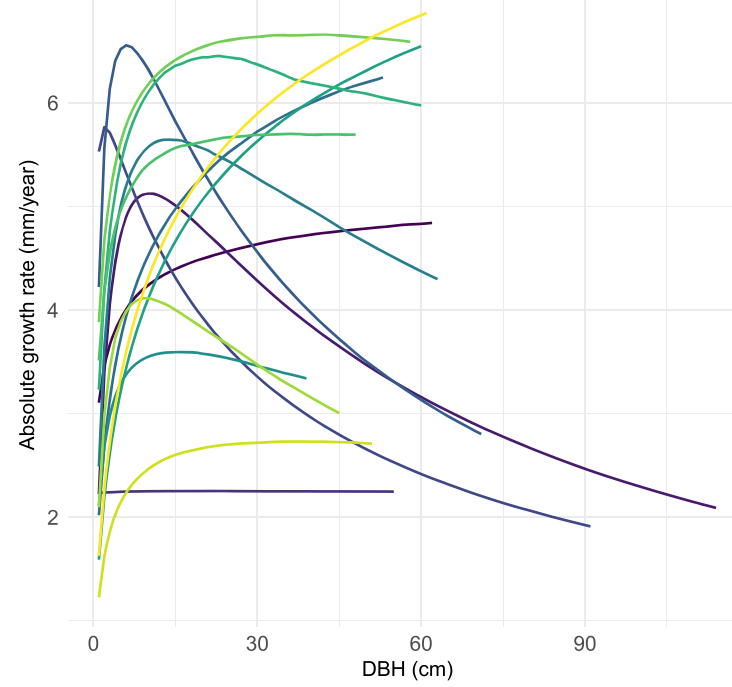

Fig. 3 Potential growth rate $\mathbf{a}$ and competition effect on growth $\mathbf{b}$ for each forest stand, predicted with the asymmetric size-dependent competition model. Plain lines are the predicted models (a: (1) and b: (4))

by insects (Valdés-Correcher et al. 2020), a process that should to some extent trigger trees' resource acquisition and ultimately tree radial growth.

No effect of stand structure on potential growth and competition functions The variation in growth patterns could not be explained by forest stand structure in terms of size, age or spatial arrangement. Concerning the effect of size structure, it has been surprising to not find any effect on growth parameters, knowing that different shapes (b) Competition effect on growth rate

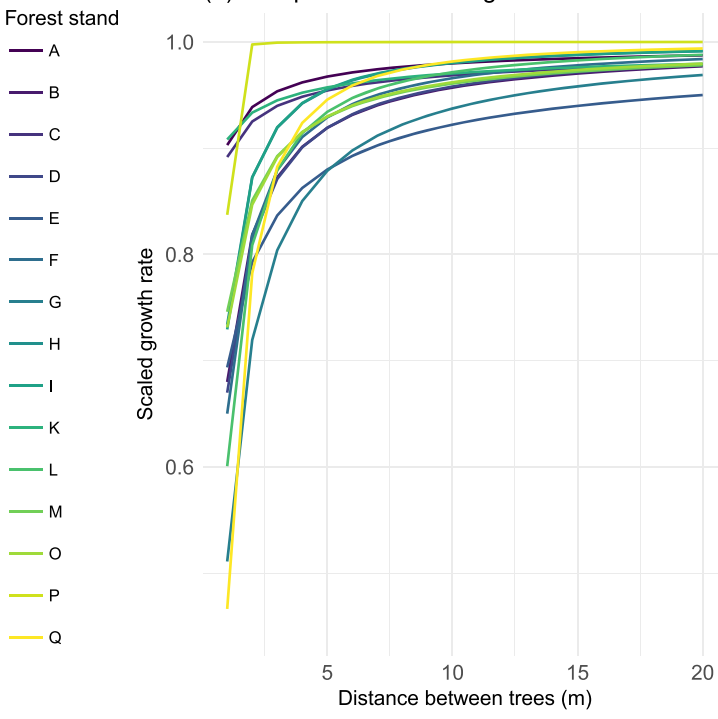

with each parameter equal to the median value of its posterior distribution. Each curve for potential growth rate was predicted for the range of observed dbh values in the corresponding forest stand

of growth functions can be statistically selected depending on the range of tree sizes covered by the data (Das 2012). Although our forest stands show different size structures, they are not skewed to very small or very large trees, which could strongly influence the shape of the growth function (Das 2012). Forest stand spatial structure showed no effect on competition parameters, suggesting that both sensitivity to competition and competition kernels do not depend on the average spatial structure of stands. Former studies have preferentially focused on whether competition coefficients
Fig. 4 Coefficients of variation across forest stands for predicted potential growth rate (1), growth-size relationship (2) and competition effect on growth (4), with the asymmetric size-dependent competition model. For each of the three processes, the boxplot displays 12 coefficients of variation

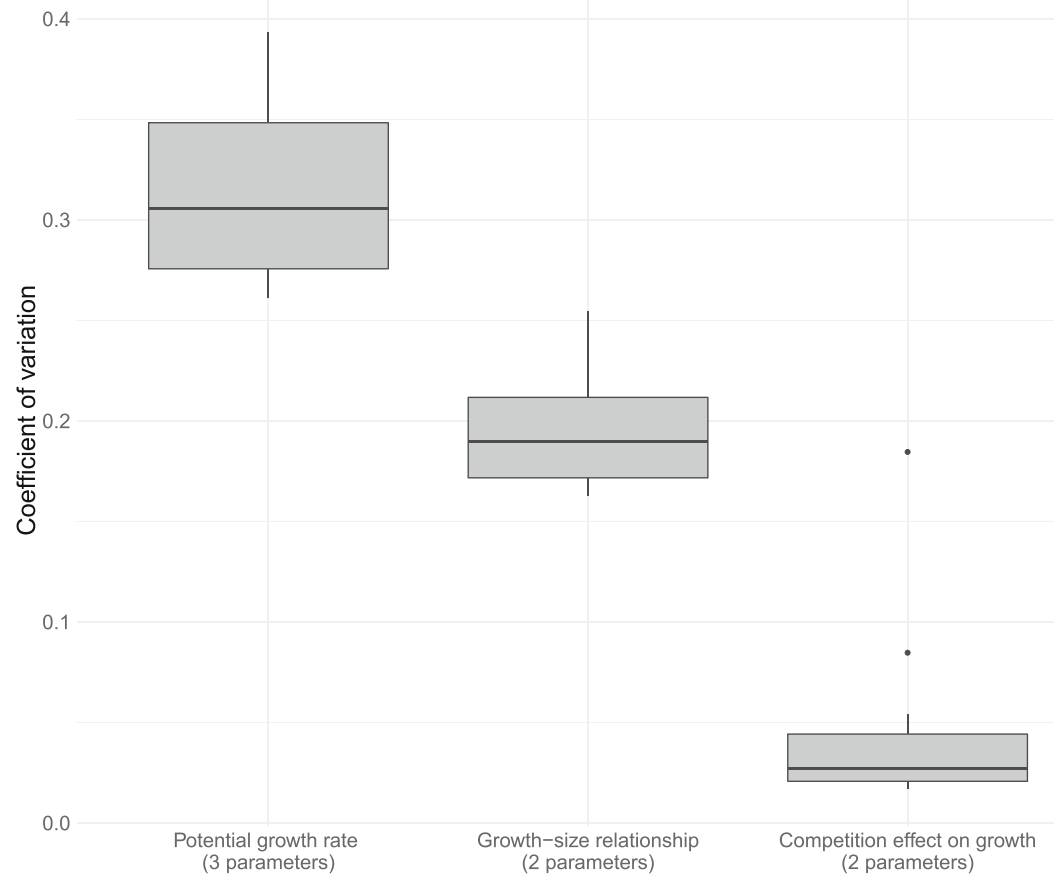




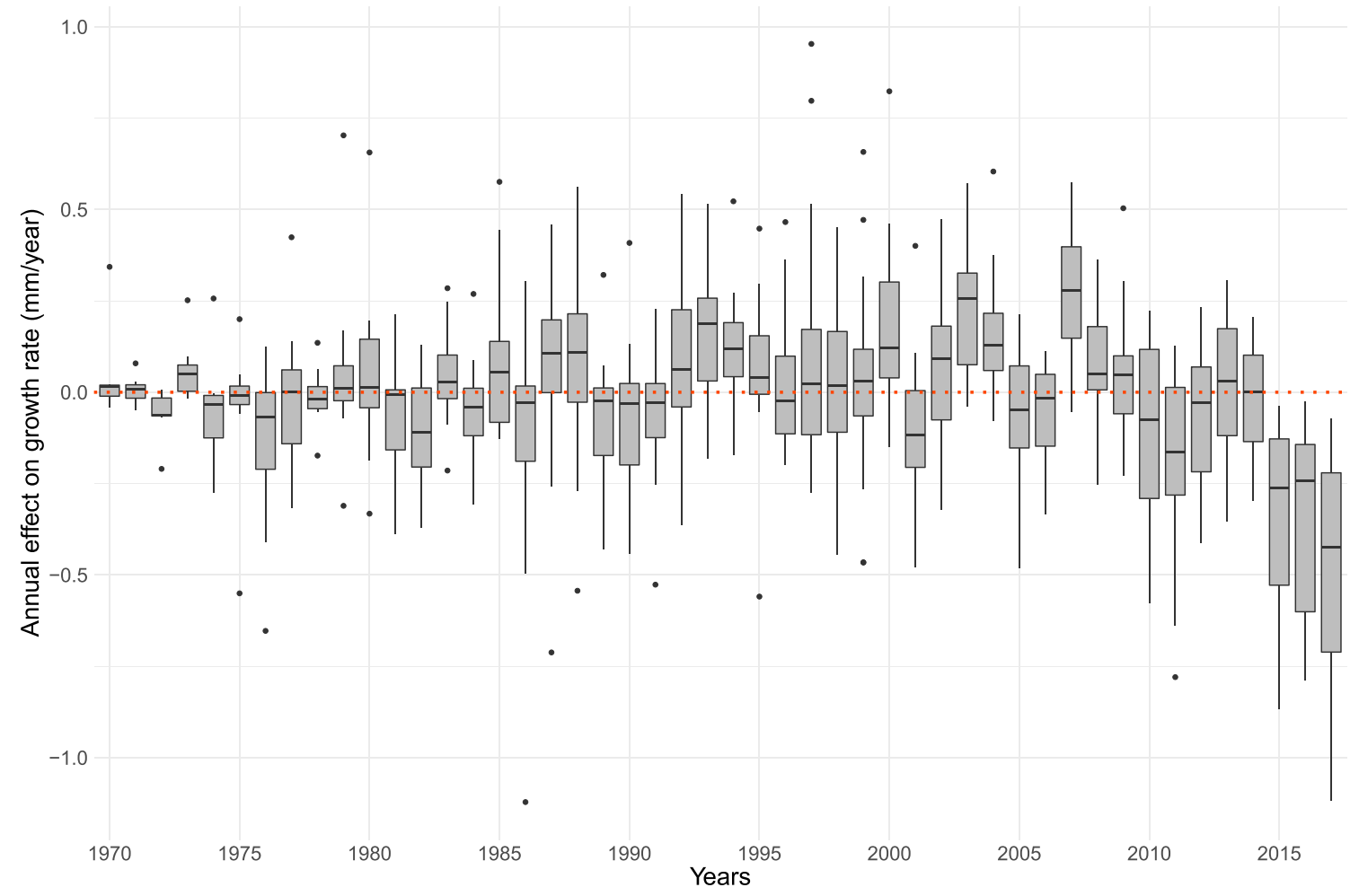

Fig. 5 Annual random effects on growth rate estimated by the asymmetric size-dependent competition model. Boxplots display the 15 means (one per forest stand) of the posterior distributions of the random effect for the given year

are influenced by spatial segregation of species, rather than the spatial arrangement of individuals per se (Freckleton and Watkinson 2001; Turnbull et al. 2004; Canham et al. 2006). However, the absence of spatial structure effects suggests that the present model included enough spatial information to describe competition. Finally, the absence of an effect of age structure on competition contrasts with the study of Masaki et al. (2006) who found that competition patterns change with stand age.

Between-year variation in tree growth In old oak forests, $29 \%$ of the variance of oak ring-width was explained by climate between 1925 and 1980 (Rozas 2011). Moreover, Alfaro-Sảnchez et al. (2020) found a positive correlation between growth and soil water moisture in June-July of the current year and September-October of the previous year, as well as a negative correlation between growth and temperature in August-September of the previous year. In our study, however, between-year variation in growth rates was overall not synchronous across stands. This could be because effects of climate variables on tree growth are age-dependent (probably because of physiological changes due to ageing) for oaks (Rozas 2005). Also, populationlevel variation in tree responses to several climate factors (precipitation, temperature, relative humidity) has been observed in silver fir (Latreille et al. 2017). Local soil, biotic and topographic conditions interact with general climatic effects, for instance leading to substantial betweensite variation in water availability between populations, which is a critical factor in pedunculate oaks, especially during early summer (Rozas 2011; Scharnweber et al. 2011). Furthermore, competition for resources was found to influence tree response to climate (Clark et al. 2014). These complex interactions between large-scale climate, stand structure and the local biotic and abiotic environment could explain why we did not find strong between-stand synchrony in annual growth rates.

\section{Conclusion and perspectives}

In this study, we modelled growth and intraspecific neighbourhood competition, including between-year variation, of 15 young stands of Quercus robur. We found that competition was overall asymmetric and size-dependent, and that competition functions were relatively similar between stands whereas potential growth functions were highly variable. Between-stand variation in model parameters could not be explained by the size, age or spatial structure of stands. Additionally, we only found moderate synchrony of annual growth rates across the forest stands. 
Our study suggests that measuring and taking into account the variability in potential growth is essential for predicting the dynamics of young tree populations. Indeed, growth rate is strongly linked to tree health and individual mortality (Hülsmann et al. 2018), which drive the survival of the population and thus may contribute to shaping spontaneous forest establishment. Similarly, growth variability between populations may have an impact on other demographic processes, such as maturity or fecundity, which are driven by individual size. Ecosystem services linked to growth, such as carbon storage, are also likely to vary between populations. In contrast, competition functions (both the spatial extent and the effect of competition) were found to be consistent, so that this process may be transferable among stands. Since stands with high potential growth rates do not show qualitatively different competition functions than stands with low potential growth, growth at low density should be a good predictor of growth in the same stand at higher density (and vice versa). Our study thus suggests that-within stands-growth measurements at a given density can be used to predict growth at different densities. This should help to predict the ecosystem functions that newly established stands of $Q$. robur will provide.

Given that population structure was not able to explain variability in growth and competition functions, investigating genetic variation in growth across populations would be of major interest. Similarly, local environmental conditions might be a source of variability to explore. In order to better understand why intraspecific competition functions were consistent across populations, it would be valuable to explore the mechanisms of competition. One could also test if the consistency of links between traits and competition found (Kunstler et al. 2016) holds for establishing forests and can help to predict their dynamics.
Acknowledgments We sincerely thank the reviewers and the editors for their important, detailed and insightful input into this manuscript.

Author contributions Contributions of the co-authors DL, JP and FMS conceived the ideas and designed methodology; EVC and DB collected the data; DL developed the model, analysed the data and wrote the manuscript; AH and FMS supervised the study and aquired the funding. All authors contributed to the final draft and gave final approval for publication.

Funding information Open Access funding provided by Projekt DEAL. D, JP and FMS were funded by the German Research Foundation (DFG, SCHU 2259/7-1) in the framework of ERA Net BiodivERsA project Sponforest.

Data availability Tree growth data are now available at the following url address https://data.inrae.fr/dataset.xhtml?persistentId=doi:10. 15454/A2JJFG

\section{Compliance with ethical standards}

Conflict of interest The authors declare that they have no conflict of interest.

Open Access This article is licensed under a Creative Commons Attribution 4.0 International License, which permits use, sharing, adaptation, distribution and reproduction in any medium or format, as long as you give appropriate credit to the original author(s) and the source, provide a link to the Creative Commons licence, and indicate if changes were made. The images or other third party material in this article are included in the article's Creative Commons licence, unless indicated otherwise in a credit line to the material. If material is not included in the article's Creative Commons licence and your intended use is not permitted by statutory regulation or exceeds the permitted use, you will need to obtain permission directly from the copyright holder. To view a copy of this licence, visit http:// creativecommonshorg/licenses/by/4.0/.

\section{Appendix}

Table 1 Model parameters

\begin{tabular}{llll}
\hline Symbol & Definition & Unit & Prior distribution \\
\hline$g_{m}$ & Maximum growth rate & mm/year & $\log _{10}\left(g_{m}\right) \sim U(-1,2)$ \\
$x_{0}$ & dbh at maximum growth rate & $\mathrm{cm}$ & $\log _{10}\left(x_{0}\right) \sim U(0,3)$ \\
$x_{b}$ & Shape of the growth curve & - & $\log _{10}\left(x_{b}\right) \sim U(-2,2)$ \\
$a$ & Sensitivity to competition & - & $\log _{10}(a) \sim U(-4,1)$ \\
$\beta$ & Scale of neighbour effect with distance & - & $\log _{10}(\beta) \sim U(-1,2)$ \\
$\phi$ & Standard deviation of growth rate inter-annual random effect & $\phi \sim U(0,5)$ \\
$\sigma$ & Standard deviation of log growth rate & - & $\log _{10}(\sigma) \sim U(-2,1)$ \\
\hline
\end{tabular}


Table $2 \Delta$ DIC of the tested models for each forest stand

\begin{tabular}{llllll}
\hline Patch & Model NC & Model SDC & Model SSC & Model ADC & Model ASC \\
\hline A & 534 & 262 & 190 & 62 & 0 \\
B & 90 & 80 & 71 & 0 & 5 \\
C & 264 & 213 & 179 & 38 & 0 \\
D & 734 & 489 & 525 & 34 & 0 \\
E & 233 & 77 & 0 & 45 & 31 \\
F & 207 & 140 & 29 & 17 & 0 \\
G & 76 & 48 & 39 & 3 & 0 \\
H & 96 & 83 & 31 & 69 & 0 \\
I & 629 & 338 & 275 & 14 & 0 \\
K & 249 & 162 & 123 & 44 & 0 \\
L & 256 & 174 & 44 & 22 & 0 \\
M & 266 & 131 & 114 & 12 & 36 \\
O & 80 & 29 & 0 & 36 & 0 \\
P & 39 & 0 & 24 & 0 & 0 \\
Q & 50 & 39 & 42 & & 0 \\
\hline
\end{tabular}

For each forest stand, the lowest DIC of the five models has been subtracted from all DICs, so that the DIC-minimal model (highlighted in italics) has a $\triangle \mathrm{DIC}$ equal to 0. Model NC, no competition; Model SDC, symmetric density-dependent competition; Model SSC, symmetric size-dependent competition; Model ADC, asymmetric density-dependent competition; Model ASC, asymmetric size-dependent competition

Table 3 Characteristics of 15 recently established stands of Quercus robur describing the spatial, size and age structure of stands

\begin{tabular}{|c|c|c|c|c|c|c|c|}
\hline $\begin{array}{l}\text { Forest } \\
\text { stand }\end{array}$ & $\begin{array}{l}\text { Patch } \\
\text { size } \\
\left(\mathrm{m}^{2}\right)\end{array}$ & $\begin{array}{l}\text { Density } \\
\text { (tree per ha) }\end{array}$ & $\begin{array}{l}\text { Mean } \\
\text { nearest } \\
\text { neighbour } \\
\text { distance }(\mathrm{m})\end{array}$ & $\begin{array}{l}\text { Mean size } \\
(\mathrm{dbh} \mathrm{cm})\end{array}$ & $\begin{array}{l}\text { Standard } \\
\text { deviation } \\
\text { of size (dbh } \\
\mathrm{cm})\end{array}$ & $\begin{array}{l}\text { Maximum } \\
\text { age } \\
\text { (years) }\end{array}$ & $\begin{array}{l}\text { Mean } \\
\text { age } \\
\text { (years) }\end{array}$ \\
\hline A & 3749 & 260 & 2.23 & 17.7 & 9.45 & 69 & 30 \\
\hline B & 1225 & 230 & 5.62 & 21.7 & 22.0 & 192 & 32 \\
\hline $\mathrm{C}$ & 1790 & 200 & 2.70 & 24.1 & 10.5 & 86 & 71 \\
\hline $\mathrm{D}$ & 3147 & 150 & 3.86 & 31.7 & 16.6 & 147 & 65 \\
\hline $\mathrm{E}$ & 1107 & 240 & 2.79 & 21.5 & 17.5 & 64 & 39 \\
\hline $\mathrm{F}$ & 1056 & 270 & 3.05 & 17.7 & 11.2 & 51 & 31 \\
\hline $\mathrm{G}$ & 5039 & 62 & 7.22 & 34.6 & 9.67 & 50 & 46 \\
\hline $\mathrm{H}$ & 2293 & 230 & 3.94 & 20.6 & 11.5 & 63 & 36 \\
\hline I & 6626 & 170 & 3.46 & 23.5 & 11.1 & 70 & 41 \\
\hline $\mathrm{K}$ & 2607 & 180 & 3.64 & 26.9 & 12.3 & 41 & 32 \\
\hline $\mathrm{L}$ & 360 & 440 & 1.38 & 21.2 & 13.4 & 71 & 34 \\
\hline M & 1457 & 400 & 4.36 & 19.6 & 14.7 & 42 & 26 \\
\hline $\mathrm{O}$ & 2832 & 92 & 4.38 & 23.8 & 10.8 & 75 & 43 \\
\hline $\mathrm{P}$ & 754 & 200 & 4.53 & 21.2 & 14.6 & 69 & 40 \\
\hline Q & 2579 & 110 & 4.33 & 27.9 & 13.7 & 71 & 35 \\
\hline
\end{tabular}


Table 4 Convergence diagnostics (95\% quantile of potential scale reduction factor) for parameters of the asymmetric size-dependent competition model fitted to data for the 15 studied stands of Quercus robur

\begin{tabular}{lllllll}
\hline Forest stand & $g_{m}$ & $x_{0}$ & $x_{b}$ & $a$ & $\beta$ & \multicolumn{1}{c}{$\phi$} \\
\hline A & 1.05 & 1.06 & 1.03 & 1.03 & 1.04 & 1.00 \\
B & 1.01 & 1.01 & 1.00 & 1.01 & 1.02 & 1.00 \\
C & 1.00 & 1.00 & 1.00 & 1.01 & 1.01 & 1.00 \\
D & 1.00 & 1.05 & 1.06 & 1.10 & 1.11 & 1.00 \\
E & 1.01 & 1.00 & 1.00 & 1.01 & 1.00 & 1.00 \\
F & 1.02 & 1.03 & 1.02 & 1.02 & 1.02 & 1.00 \\
G & 1.00 & 1.00 & 1.00 & 1.04 & 1.04 & 1.00 \\
H & 1.00 & 1.04 & 1.03 & 1.01 & 1.00 & 1.00 \\
I & 1.03 & 1.02 & 1.02 & 1.06 & 1.07 & 1.00 \\
K & 1.01 & 1.08 & 1.04 & 1.01 & 1.03 & 1.00 \\
L & 1.00 & 1.02 & 1.05 & 1.00 & 1.00 & 1.00 \\
M & 1.01 & 1.01 & 1.01 & 1.06 & 1.05 & 1.00 \\
O & 1.00 & 1.01 & 1.00 & 1.00 & 1.00 & 1.00 \\
P & 1.02 & 1.04 & 1.03 & 1.01 & 1.00 & 1.00 \\
Q & 1.00 & 1.01 & 1.01 & 1.02 & 1.02 & 1.00 \\
\hline
\end{tabular}

Approximate convergence of the Markov chain Monte Carlo algorithm is diagnosed when the $95 \%$ quantile of potential scale reduction factor is close to 1 . See Table 1 for parameter definition

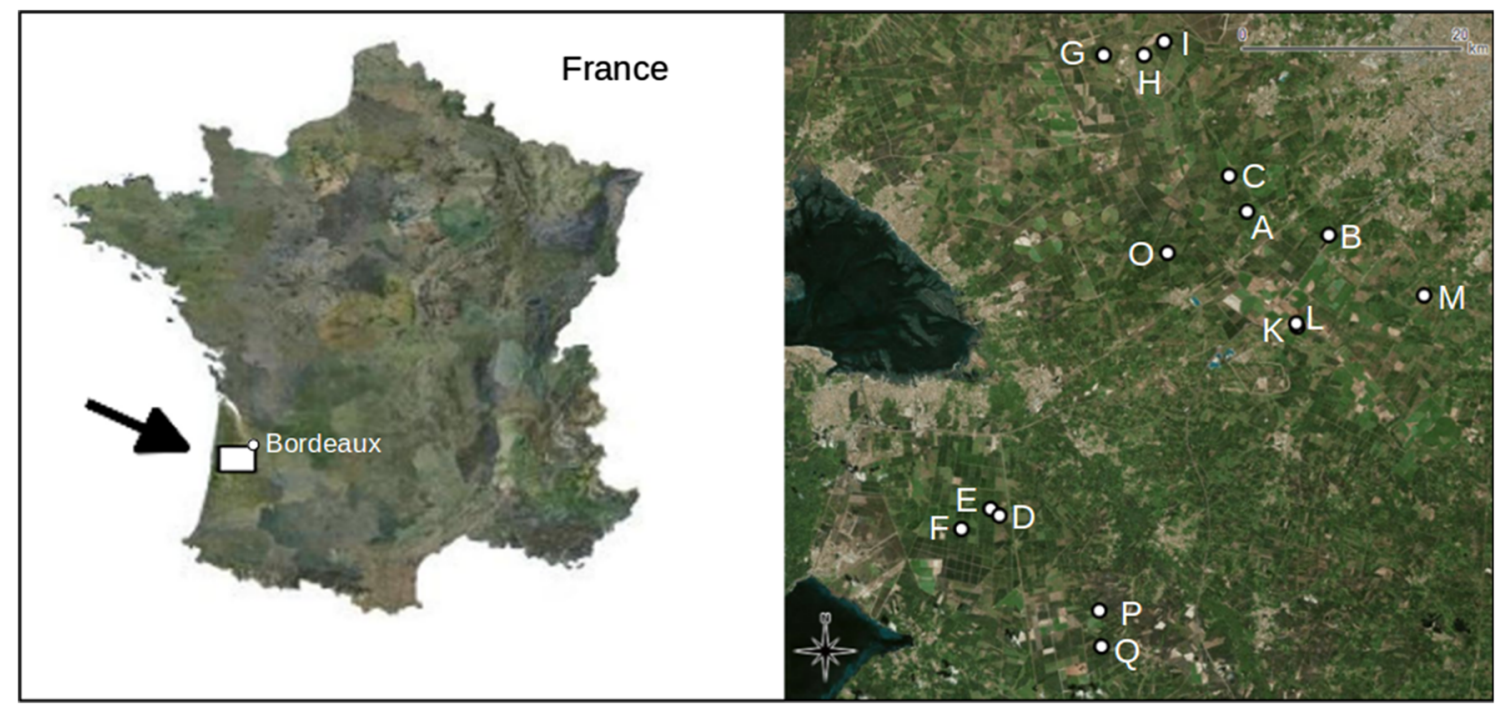

Fig. 6 Localisation of the study region and the 15 studies stands of Quercus robur (Valdès-Correcher et al. 2019) 


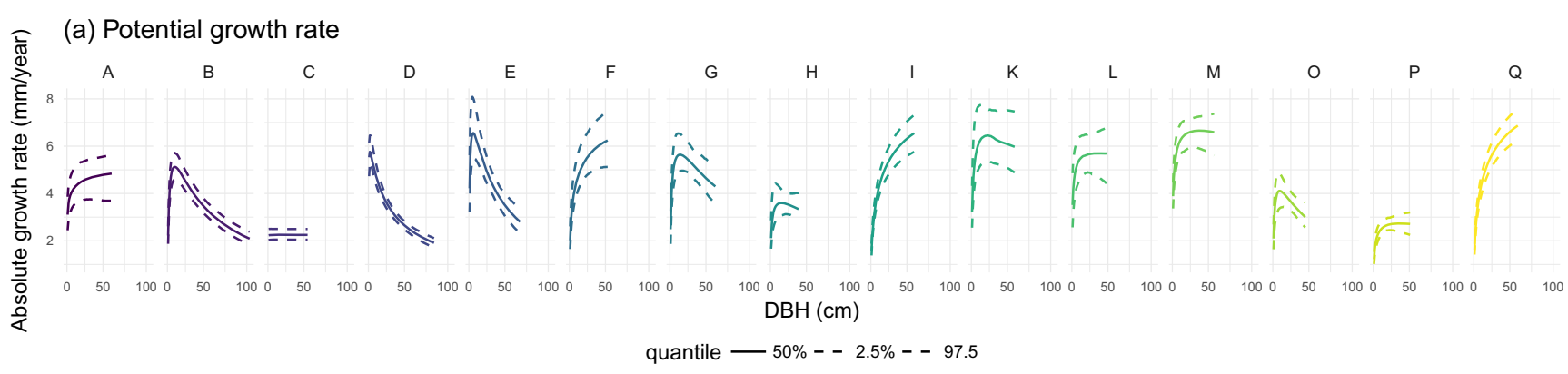

(b) Competition effect on growth rate

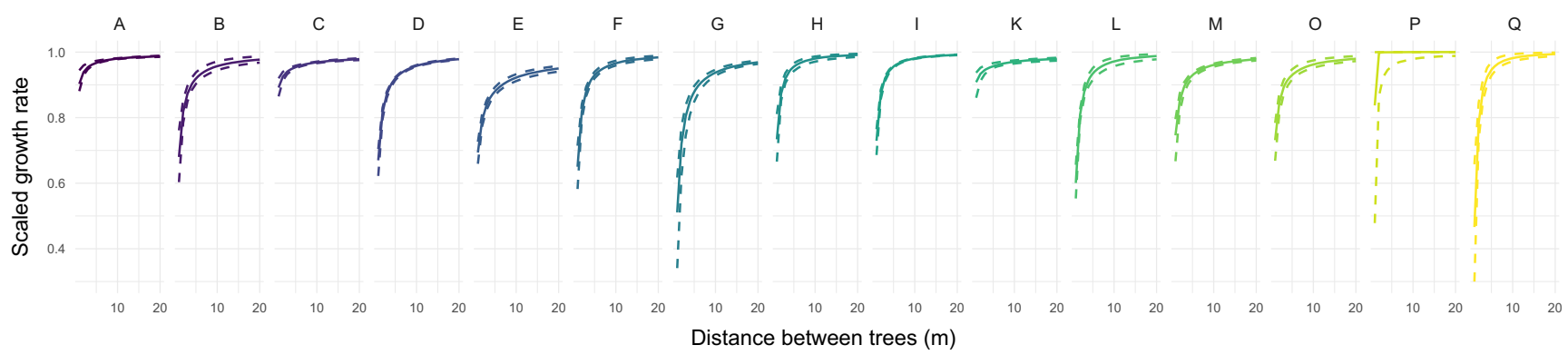

Fig. 7 Growth function $\mathbf{a}$ and competition effect on growth $\mathbf{b}$ for each

each parameter equal to the median value of its posterior distribution; forest stand, predicted with the asymmetric size-dependent competidashed lines delimit the $95 \%$ credibility envelope of predictions tion model. Solid lines are model predictions (a: (1) and b: (4)) with 


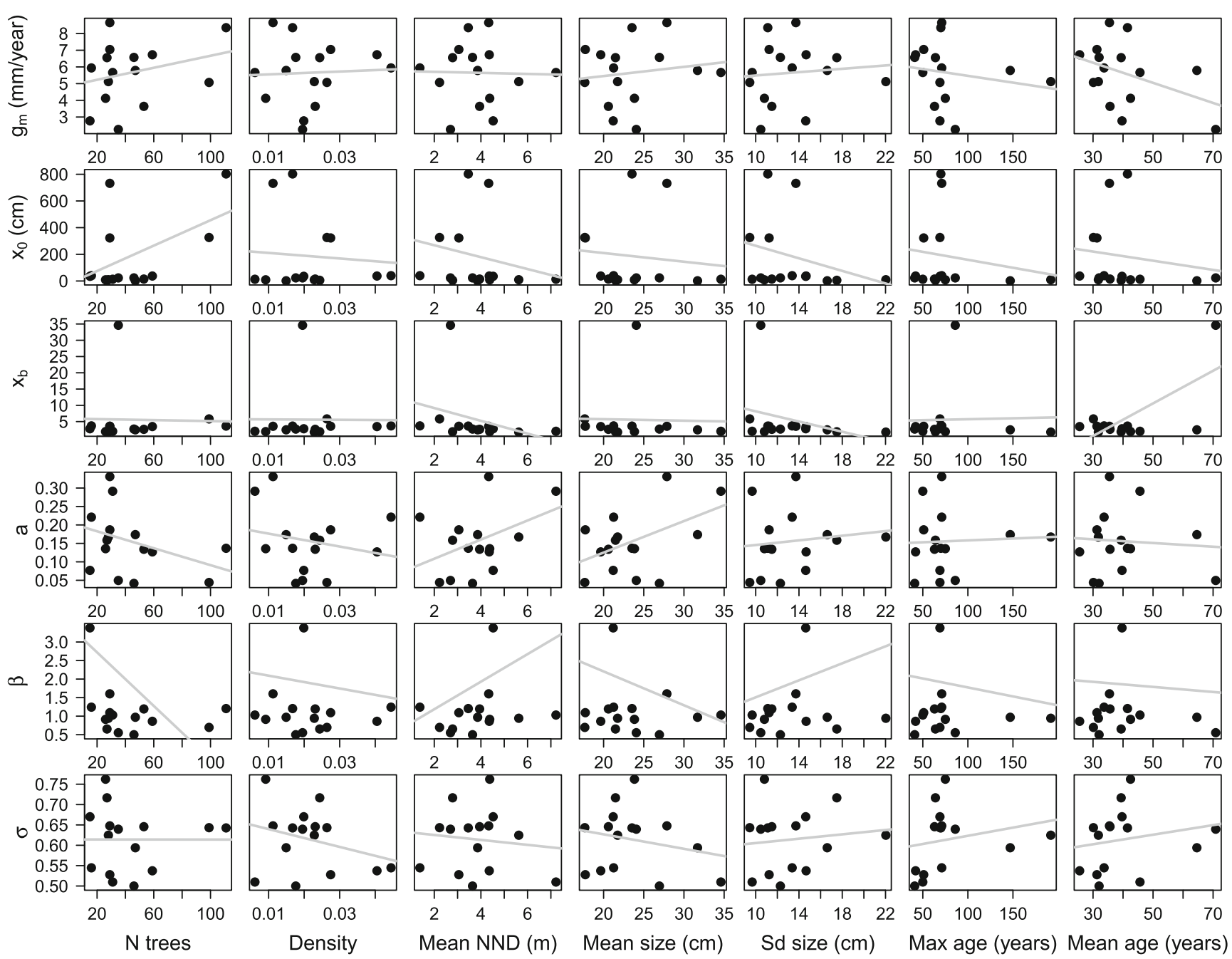

Fig. 8 Relationship between forest stand structure variables (see Appendix Table 3) and forest stand-level medians of the parameters (see Table 1 for parameter definition) of the asymmetric size-dependent competition model. Lines show average regressions (using the mean of the intercepts and slopes estimated with the bootstrap linear regressions). NND denotes the nearest neighbour distance 


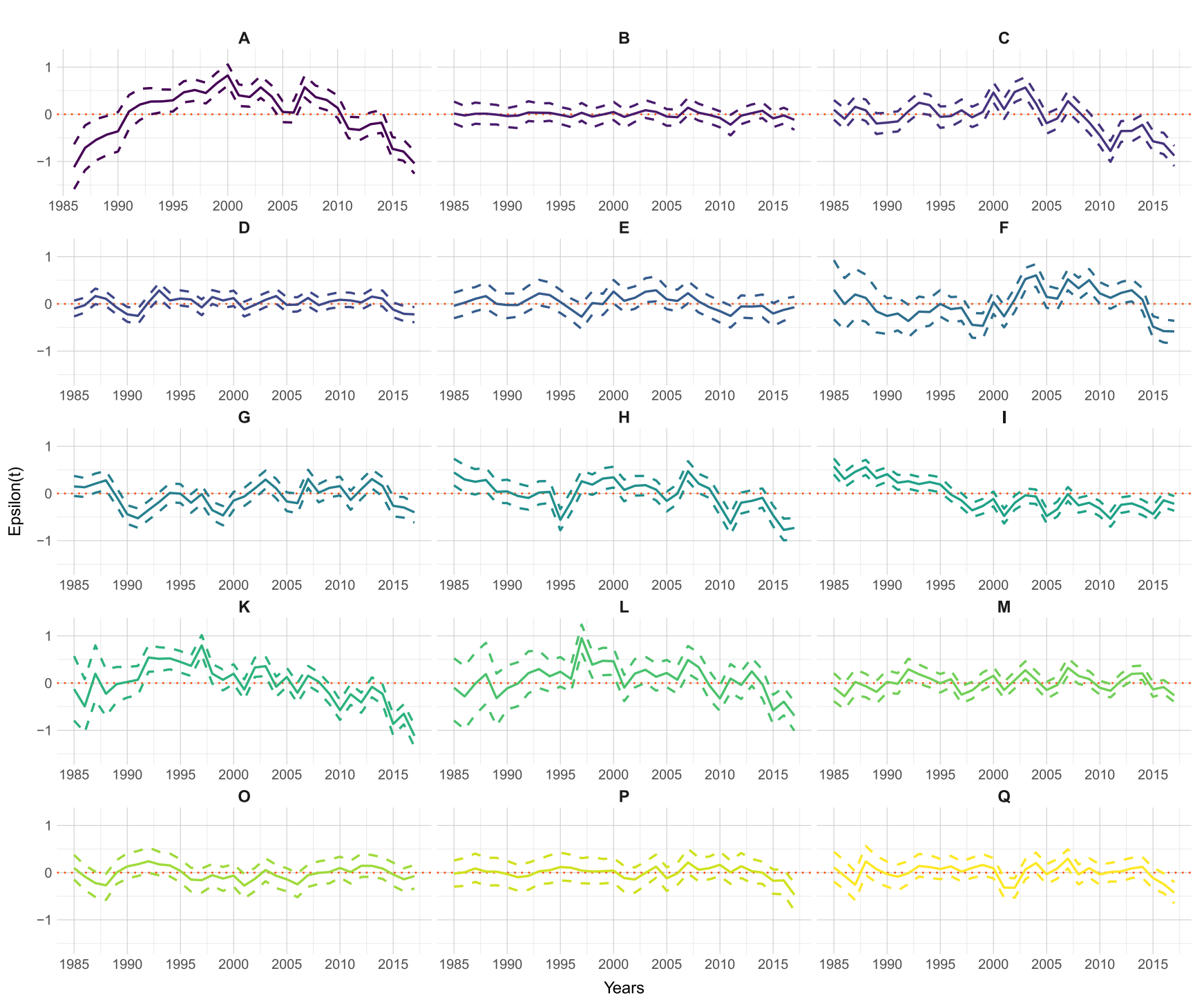

Fig. 9 Annual random effects on growth rate for each forest stand estimated by the asymmetric size-dependent competition model. Solid lines are the median values and dashed lines delimit the $95 \%$ credibility intervals 


\section{References}

Alfaro-Sảnchez R, Jump AS, Pino J, Diez-Nogales O, Espelta JM (2019) Land use legacies drive higher growth, lower wood density and enhanced climatic sensitivity in recently established forests. Agricul Forest Meteorol 276-277(June):107630. https://doi.org/ 10.1016/j.agrformet.2019.107630

Alfaro-Sảnchez R, Valdès-Correcher E, Espelta JM, Hampe A, Bert D (2020) How do social status and tree architecture influence radial growth, wood density and drought response in spontaneously established pedunculate oak (Quercus robur) forests? Ann For Sci 77:49. https://doi.org/10.1007/s13595-020-00949-x

Allan GJ, Shuster SM, Woolbright SA, Walker F, Meneses N, Keith A, Bailey J, Whitham TG (2012) Perspective: interspecific indirect genetic effects (IIGEs). Linking genetics and genomics to community ecology and ecosystem processes. Trait-Mediated Indirect Interactions: Ecological and Evolutionary Perspectives, pp. 295-323

Atwood RA, White TL, Huber DA (2002) Genetic parameters and gains for growth and wood properties in Florida source loblolly pine in the southeastern United States. Can J For Res 32(6):10251038. https://doi.org/10.1139/x02-025

Bates D, Mächler M, Bolker B, Walker S (2015) Fitting linear mixedeffects models using lme4. J Stat Softw 67(1):1-48

Bella IE (1971) A new competition model for individual trees. Forest Science:364-372. https://doi.org/10.1093/forestscience/17.3.364

Berger U, Hildenbrandt H (2000) A new approach to spatially explicit modelling of forest dynamics: spacing, ageing and neighbourhood competition of mangrove trees. Ecol Model 132(3):287-302. https://doi.org/10.1016/S0304-3800(00)00298-2

Bert D, Hampe A (2020) Dendrochronology of 661 Quercus robur for SPONFOREST Project. [Dataset], Portail Data INRAE V1. https://doi.org/10.15454/A2JJFG

Bourdier T, Cordonnier T, Kunstler G, Piedallu C, Lagarrigues G, Courbaud B (2016) Tree size inequality reduces forest productivity: an analysis combining inventory data for ten European species and a light competition model. PLoS ONE 11(3):1-14. https://doi.org/10.1371/journal.pone.0151852

Buechling A, Martin PH, Canham CD (2017) Climate and competition effects on tree growth in Rocky Mountain forests. J Ecol 105(6):1636-1647. https://doi.org/10.1111/1365-2745.12782

Bugmann H (2001) A review of forest gap models. Clim Chang 51(3-4):259-305. https://doi.org/10.1023/A:1012525626267

Canham CD, Lepage PT, Coates KD (2004) A neighborhood analysis of canopy tree competition : effects of shading versus crowding. Can J For Res 34:778-787. https://doi.org/10.1139/x03-232

Canham CD, Papaik MJ, Uriarte M, McWilliams WH, Jenkins JC, Twery MJ (2006) Neighborhood analyses of canopy tree competition along environmental gradients in New England forests. Ecol Appl 16(2):540-554. https://doi.org/10.1890/1051-0761

Canham CD, Murphy L, Riemann R, McCullough R, Burrill E (2018) Local differentiation in tree growth responses to climate. Ecosphere 9(8). https://doi.org/10.1002/ecs2.2368

Clark JS (2010) Individuals and the variation needed for high species diversity in forest trees. Science 327:1129-1132. https://doi.org/ 10.1126/science. 1183506

Clark JS, Bell DM, Kwit MC, Zhu K (2014) Competition-interaction landscapes for the joint response of forests to climate change. Glob Chang Biol 20(6):1979-1991. https://doi.org/10.1111/gcb.12425

Coates KD, Canham CD, LePage PT (2009) Above- versus belowground competitive effects and responses of a guild of temperate tree species. J Ecol 97(1):118-130. https://doi.org/10.1111/j.13652745.2008.01458.x

Coll M, Penuelas J, Ninyerola M, Pons X, Carnicer J (2013) Multivariate effect gradients driving forest demographic responses in the
Iberian Peninsula. For Ecol Manag 303:195-209. https://doi.org/ 10.1016/j.foreco.2013.04.010

Cruz-Alonso V, Villar-Salvador P, Ruiz-Benito P, Ibảnez I, ReyBenayas JM (2019) Long-term dynamics of shrub facilitation shape the mixing of evergreen and deciduous oaks in Mediterranean abandoned fields. Journal of Ecology:1-13. https://doi.org/ $10.1111 / 1365-2745.13309$

Das A (2012) The effect of size and competition on tree growth rate in old-growth coniferous forests. Can J For Res 42(11):1983-1995. https://doi.org/10.1139/x2012-142

Davis MA, Curran C, Tietmeyer A, Miller A (2005) Dynamic tree aggregation patterns in a species-poor temperate woodland disturbed by fire. J Veg Sci 16(2):167-174. https://doi.org/10.1111/j. 1654-1103.2005.tb02352.x

Dobbertin M, Baltensweiler A, Rigling D (2001) Tree mortality in an unmanaged mountain pine (Pinus mugo var. uncinata) stand in the Swiss National Park impacted by root rot fungi. For Ecol Manag 145(1-2):79-89. https://doi.org/10.1016/S0378-1127(00)00576-4

Unece F. A. O (2015) State of Europe's forests 2015. FOREST EUROPE, Liaison Unit Madrid

Fraver S, D'Amato AW, Bradford JB, Jonsson BG, Jónsson M, Esseen PA (2014) Tree growth and competition in an old-growth Picea abies forest of boreal Sweden: influence of tree spatial patterning. J Veg Sci 25(2):374-385. https://doi.org/10.1111/jvs.12096

Freckleton RP, Watkinson AR (2001) Predicting competition coefficients for plant mixtures: reciprocity, transitivity and correlations with life-history traits. Ecol Lett 4(4):348-357. https://doi.org/10.1046/j.1461-0248.2001.00231.x

Fuchs R, Herold M, Verburg PH, Clevers JGPW (2013) A highresolution and harmonized model approach for reconstructing and analysing historic land changes in Europe. Biogeosciences 10(3):1543-1559. https://doi.org/10.5194/bg-10-15432013

Gelman A, Rubin DB (1992) Inference from iterative simulation using multiple sequences. Stat Sci 7(4):457-511. https://doi.org/10. $1214 / \mathrm{ss} / 1177011136$

Gelman A, Goodrich B, Gabry J, Ali I (2018) R-squared for Bayesian regression models - the problem defining R2 based on the variance of estimated prediction errors. American Statistician. https://doi.org/10.1080/00031305.2018.1549100

Gerzabek G, Oddou-Muratorio S, Hampe A (2017) Temporal change and determinants of maternal reproductive success in an expanding oak forest stand. J Ecol 105:39-48. https://doi.org/10.1111/ 1365-2745.12677

Gómez-Aparicio L, Garcia-Valdès R, Ruiz-Benito P, Zavala MA (2011) Disentangling the relative importance of climate, size and competition on tree growth in Iberian forests: implications for forest management under global change. Glob Chang Biol 17(7):2400-2414. https://doi.org/10.1111/j.1365-2486.2011.02421.x

Hansen EM, Goheen EM (2000) Phellinus weirii and other native root pathogens as determinants of forest structure and process in western North America. Ann Rev Phytopathol 38:515-539. https://doi.org/10.1146/annurev.phyto.38.1.515

Hegyi F (1974) A simulation model for managing jack-pine stands simulation. Royalcoll Res Notes 30:74-90

Húlsmann L, Bugmann H, Cailleret M, Brang P (2018) How to kill a tree - empirical mortality models for eighteen species and their performance in a dynamic forest model. Ecol Appl 0(0):1-19. https://doi.org/10.1002/eap.1668

Díaz S, Settele J, Brondizio ES, Ngo HT, Gueze M, Agard J, Arneth A, Balvanera P, Brauman KA, Butchart SHM, Chan KMA, Garibaldi LA, Ichii K, Liu J, Subramanian SM, Midgley GF, Miloslavich P, Molnár Z, Obura D, Pfaff A, Polasky S, Purvis A, Razzaque J, Reyers B, Chowdhury RR, Shin YJ, Visseren-Hamakers IJ, Willis KJ, Zayas CN (eds) (2019) IPBES. Summary for policymakers 
of the global assessment report on biodiversity and ecosystem services of the Intergovernmental Science-Policy Platform on Biodiversity and Ecosystem Services. IPBES secretariat, Bonn

Kunstler G, Falster D, Coomes DA, Hui F, Kooyman RM, Laughlin DC, Poorter L, Vanderwel M, Vieilledent G, Wright SJ, Aiba M, Baraloto C, Caspersen J, Cornelissen JHC, Gourlet-Fleury S, Hanewinkel M, Herault B, Kattge J, Kurokawa H, Onoda Y, Penuelas J, Poorter H, Uriarte M, Richardson S, Ruiz-Benito P, Fang Sun I, Ståhl G, Swenson NG, Thompson J, Westerlund B, Wirth C, Zavala MA, Zeng H, Zimmerman JK, Zimmermann NE, Westoby M (2016) Plant functional traits have globally consistent effects on competition. Nature 529(7585):204-207. https://doi.org/10.1038/nature16476

Latreille A, Davi H, Huard F, Pichot C (2017) Variability of the climate-radial growth relationship among Abies alba trees and populations along altitudinal gradients. Forest Ecol Manag 396:150-159. https://doi.org/10.1016/j.foreco.2017.04.012

Linares JC, Camarero JJ, Carreira JA (2010) Competition modulates the adaptation capacity of forests to climatic stress: Insights from recent growth decline and death in relict stands of the Mediterranean fir Abies pinsapo. J Ecol 98(3):592-603. https://doi.org/10.1111/j.1365-2745.2010.01645.x

Lorimer CG (1983) Tests of age-independent competition indices for individual trees in natural hardwood stands. For Ecol Manag 6(4):343-360

Madrigal-Gonzälez J, Zavala MA (2014) Competition and tree age modulated last century pine growth responses to high frequency of dry years in a water limited forest ecosystem. Agricul Forest Meteorol 192-193:18-26. https://doi.org/10.1016/j.agrformet.2014.02. 011

Masaki T, Mori S, Kajimoto T, Hitsuma G, Sawata S, Mori M, Osumi K, Sakurai S, Seki T (2006) Long-term growth analyses of Japanese cedar trees in a plantation: neighborhood competition and persistence of initial growth deviations. J For Res 11(4):217225. https://doi.org/10.1007/s10310-005-0175-6

Nottebrock H, Schmid B, Treurnicht M, Pagel J, Esler KJ, Bỏhninggaese K, Schleuning M, Schurr FM (2017) Coexistence of plant species in a biodiversity hotspot is stabilized by competition but not by seed predation. Oikos 126:276-284. https://doi.org/10.11 11/oik.03438

Pacala SW, Canham CD, Saponara J, Silander Jr. JA, Kobe RK, Ribbens E (1996) Forest models defined by field measurements: estimation, error analysis and dynamics. Ecol Monogr 66(1):1-43. https://doi.org/10.2307/2963479

Potapov PV, Turubanova SA, Tyukavina A, Krylov AM, McCarty JL, Radeloff VC, Hansen MC (2015) Eastern Europe's forest cover dynamics from 1985 to 2012 quantified from the full Landsat archive. Remote Sens Environ 159:28-43. https://doi.org/10.1016/ j.rse.2014.11.027

Plummer M (2009) rjags: Bayesian graphical models using mcmc. Rpackage version 1.0.3-12

R Core Team (2018) R: a language and environment for statistical computing $r$ foundation for statistical computing, Vienna

Rademacher C, Neuert C, Grundmann V, Wissel C, Grimm V (2004) Reconstructing spatiotemporal dynamics of Central European natural beech forests: the rule-based forest model BEFORE. For Ecol Manag 194(1-3):349-368. https://doi.org/10.1016/j.foreco. 2004.02.022

Ramirez JA, Diaz M (2008) The role of temporal shrub encroachment for the maintenance of Spanish holm oak Quercus ilex dehesas. For Ecol Manag 255(5-6):1976-1983. https://doi.org/10.1016/j. foreco.2007.12.019

Rasmussen CR, Weisbach AN, Thorup-Kristensen K, Weiner J (2019) Size-asymmetric root competition in deep, nutrient-poor soil. J Plant Ecol 12(1):78-88. https://doi.org/10.1093/jpe/rtx064
Rey Benayas JM, Bullock JM (2012) Restoration of biodiversity and ecosystem services on agricultural land. Ecosystems 15(6):883899. https://doi.org/10.1007/s10021-012-9552-0

Rey Benayas JM, Martínez-Baroja L, Perez-Camacho L, VillarSalvador P, Holl KD (2015) iNez-baroja L Predation and aridity slow down the spread of 21-year-old planted woodland islets in restored Mediterranean farmland. Forest 46(5-6):841-853. https://doi.org/10.1007/s11056-015-9490-8

Rigg LS (2005) Disturbance processes and spatial patterns of two emergent conifers in New Caledonia. Austral Ecol 30(4):363-373. https://doi.org/10.1111/j.1442-9993.2005.01444.x

Rozas V (2005) Dendrochronology of pedunculate oak (Quercus robur L.) in an old-growth pollarded woodland in northern Spain: treering growth responses to climate. Ann Forest Sci 62:209-218. doi:https://doi.org/10.1051/forest:2005012

Rozas V (2011) Detecting the impact of climate and disturbances on tree-rings of Fagus sylvatica L. and Quercus robur L. in a lowland forest in Cantabria, Northern Spain. Ann Forest Sci 58:237-251. https://doi.org/10.1051/forest:2001123

Ruiz-Benito P, Madrigal-Gonzȧlez J, Ratcliffe S, Coomes DA, Kandler G, Lehtonen A, Wirth C, Zavala MA (2014) Stand structure and recent climate change constrain stand basal area change in European forests: a comparison across boreal, temperate, and Mediterranean biomes. Ecosystems 17(8):14391454. https://doi.org/10.1007/s10021-014-9806-0

Saxe H, Cannell MGR, Johnsen Ø, Ryan MG, Vourlitis G (2001) Tree and forest functioning in response to global warming. Phytol 149(3):369-400. https://doi.org/10.1046/j.1469-8137.2001.00 057. $\mathrm{x}$

Scharnweber T, Manthey M, Criegee C, Bauwe A, Schroder C, Wilmking M (2011) Forest ecology and management drought matters - declining precipitation influences growth of Fagus sylvatica L. and Quercus robur L. in north-eastern Germany. For Ecol Manag 262(6):947-961. https://doi.org/10.1016/j.foreco.2011.05. 026

Schenk HJ (2006) Root competition: Beyond resource depletion. J Ecol 94(4):725-739. https://doi.org/10.1111/j.1365-2745.2006. 01124.x

Schroter D, Cramer W, Leemans R, Prentice IC, Araujo MB, Arnell NW, Bondeau A, Bugmann H, Carter TR, Gracia CA, De La Vega-Leinert AC, Erhard M, Ewert F, Glendining M, House JI, Kankaanpȧȧ S, Klein RJT, Lavorel S, Lindner M, Metzger MJ, Meyer J, Mitchell TD, Reginster I, Rounsevell M, Sabate S, Sitch S, Smith B, Smith J, Smith P, Sykes MT, Thonicke K, Thuiller W, Tuck G, Zaehle S, Zierl B (2005) Ecosystem service supply and vulnerability to global change in Europe. Science 310(5752):1333-1337. https://doi.org/10.1126/science.1115233

Schweingruber FH (1988) Tree rings. Basics and applications of dendrochronology. Dordrecht, Reidel Publ. (English Edition), pp 276

Schwinning S, Weiner J (1998) Mechanisms determining the degree of size asymmetry in competition among plants. Oecologia 113(4):447-455. https://doi.org/10.1007/s004420050397

Song XP, Hansen MC, Stehman SV, Potapov PV, Tyukavina A, Vermote EF, Townshend JR (2018) Global land change from 1982 to 2016. Nature 560(7720):639-643. https://doi.org/10.1038/s415 86-018-0411-9

Spiegelhalter DJ, Best NG, Carlin BP, van der Linde A (2002) Bayesian measures of model complexity and fit. J R Stat Soc Ser B (Stat Methodol) 64(4):583-639. https://doi.org/10.1111/14679868.00353

Stadt KJ, Huston C, Coates KD, Feng Z, Dale MRT, Lieffers VJ (2007) Evaluation of competition and light estimation indices for predicting diameter growth in mature boreal mixed forests. Ann Forest Sci 64(2):477-490. https://doi.org/10.1051/forest:2007025 
Turnbull LA, Coomes D, Hector A, Rees M (2004) Seed mass and the competition/colonization trade-off: competitive interactions and spatial patterns in a guild of annual plants. J Ecol 92(1):97-109. https://doi.org/10.1111/j.1365-2745.2004.00856.x

Uriarte M, Canham CD, Thompson J, Zimmerman JK (2004a) A neighborhood analysis of tree growth and survival in a hurricane-driven tropical forest. Ecol Monogr 74(4):591-614. https://doi.org/10.1890/03-4031

Uriarte M, Condit R, Canham CD, Hubbell SP (2004b) A spatially explicit model of sapling growth in a tropical forest: does the identity of neighbors matter. J Ecol 92:348-360. https://doi.org/10.1111/j.0022-0477.2004.00867.x

Valdès-Correcher E, van Halder I, Barbaro L, Castagneyrol B, Hampe A (2019) Insect herbivory and avian insectivory in novel native oak forests: Divergent effects of stand size and connectivity. For Ecol Manag 445:146-153. https://doi.org/10.1016/j.foreco.2019.05.018

Valdés-Correcher E, Bourdin A, González-Martínez SC, Moreira X, Galmán A, Castagneyrol B, Hampe A (2020) Leaf chemical defences and insect herbivory in oak: accounting for canopy position unravels marked genetic relatedness effects. Ann Botany:mcaa101. https://doi.org/10.1093/aob/mcaa101
Vilà-Cabrera A, Espelta JM, Vayreda J, Pino J (2017) "New forests" from the twentieth century are a relevant contribution for $\mathrm{C}$ storage in the Iberian Peninsula. Ecosystems 20(1):130-143. https://doi.org/10.1007/s10021-016-0019-6

Whitham TG, Bailey JK, Schweitzer JA, Shuster SM, Bangert RK, CLeroy CJ, Lonsdorf EV, Allan GJ, DiFazio SP, Potts BM, Fischer DG, Gehring CA, Lindroth RL, Marks JC, Hart SC, Wimp GM, Wooley SC (2006) A framework for community and ecosystem genetics: from genes to ecosystems. Nat Rev Genet 7(7):510-523. https://doi.org/10.1038/nrg1877

Wimberly MC, Bare BB (1996) Distance-dependent and distanceindependent models of douglas-fir and western hemlock basal area growth following silvicultural treatment. For Ecol Manag 89(1-3):1-11. https://doi.org/10.1016/S0378-1127(96)03870-4

Wood DL, Koerber TW, Scharpf RF (2003) Pests of the native California conifers. University of California Press, Berkeley

Wright EF, Canham CD, Coates KD (2000) Effects of suppression and release on sapling growth for 11 tree species of northern, interior British Columbia. Can J For Res 30(10):1571-1580. https://doi.org/10.1139/x00-089

Publisher's note Springer Nature remains neutral with regard to jurisdictional claims in published maps and institutional affiliations.

\section{Affiliations}

Dominique Lamonica $^{1} \cdot$ Joern Pagel $^{1} \cdot$ Elena Valdés-Correcher $^{2} \cdot$ Didier Bert $^{2} \cdot$ Arndt Hampe $^{2} \cdot$ Frank M. Schurr $^{1}$

Joern Pagel

joern.pagel@uni-hohenheim.de

Elena Valdés-Correcher

elena.valdes-correcher@inrae.fr

Didier Bert

didier.bert@inrae.fr

Arndt Hampe

arndt.hampe@inrae.fr

Frank M. Schurr

frank.schurr@uni-hohenheim.de

1 Institute of Landscape and Plant Ecology, University of Hohenheim, Stuttgart, Germany

2 BIOGECO INRAE UMR 1202 University of Bordeaux, Pessac 33400, France 